\title{
Production and Technique in the Iron and Steel Industry in Japan during 1972
}

\section{By Tsuneyo IKI*}

\section{Introduction}

For a long time in the post-war period iron and steel industry of Japan continued its growth as a basic industry and encouraged recovery and development of industries in general in the country. The crude steel output in Japan expanded four times in the decade beginning in 1960: while the crude steel output in 1960 amounted to $23160000 \mathrm{t}$, that of 1970 was 92400000 t showing a high growth rate of $14.8 \%$ per average year. However, in 1971 the crude steel output decreased to $88440000 \mathrm{t}$ and indicated a slowdown phenomena arising from recessive features in the Japanese economy.

The decrease in growth rate which had been kept high by large equipment investment from private sources was a reflection of the Japanese economy having already achieved initial objectives of consolidating the heavy and chemical industries, strengthening the competitive power in international markets, and expanding the productivity in the post-war period; it entered into a prolonged recessive period starting from the summer of 1970 as it faced with crucial imbalance in supply and demand, increased cost such as labor cost, air pollution problems, unfavourable developments in international economic conditions, and other difficult factors. Changes in economic conditions in the world, such as enforcement of a new economic policy in the United States since August, 1971, and a large up-valuation of yen in December of the same year led the Japanese economy to a new stage.

The domestic economy in 1972 at last began to show recovery from the prolonged recession covered over the manufacturng industries and the heavy and chemical industries. Increase in individual consumption in the private sector and increase in the government investment in public facilities contributed to the recovery. With respect to the iron and steel output, because the gap between supply and demand had become so acute, in spite of the estimated crude steel productivity of $120000000 \mathrm{t}$ per year, every company had to take concerted output reduction measures to endure through the inactive market conditions.

Namely, toward the end of 1971, the six blast furnace companies established a crude steel cartel to meet the depression. The term was extended until the end of 1972 since business conditions of the member companies had not improved by June, of that year.

In March, 1972, the fifty-eight electric furnace companies also formed a cartel in an effort to minimize the gap in supply and demand that tended to enlarge as new facilities started operations in 1971 and 1972. The cartel lasted until the end of the year.

Special steel makers were not free from the effect of the recession: cartels for structural alloy steels and stainless steel plates were also formed. These measures taken by the industry resulted in reduction of crude steel output: output for the period from April to September was $47500000 \mathrm{t}$, registering 7\% decrease from the corresponding period of the previous year.

However, since the mid-year the demand for steel in construction and machinery industries began to pick up, and the stock of steel materials started to decrease. Thus the cartels for depression began to show some effects, and the supply and demand relations are now on the improvement.

The 1972 was a year of significant changes in socioeconomic conditions. With respect to domestic problems of intensification of over- and under-populated areas, a decisive measure was taken by enactment of the Promotion of Relocation of Industries Law (June). Thus, the first step was taken to apply the idea of remodeling the Japanese archipelago into practice.

As for international relations, a long-waited restoration of diplomatic relations between Japan and China was realized in September. Even after adjustment of international currencies at the end of 1971, Japanese exports continued to step up, and the amount of foreign currency reserve reached $\$ 17790000000$ at the end of October, 1972. In such circumstances stimulation of importation became a major task in the Japanese economy: in November, custom tarrifs were lowered; further in November, for the purpose of promoting importation and consolidating public capital, the government made a major amendment to the budget. Thanks to these governmental policies and as efforts in the private sector to adjust stock proceeded, signs of gradual recovery began to appear in the domestic economy.

In the fall the government made revisions on the original economic estimates. As for GNP (gross national products, actual) initial estimate of $7.2 \%$ increase over the previous year was amended to $9.5 \%$ increase.

As described above, after August internal economic conditions turned into the recovery trend. Characteristics of this economic recovery process were that the pattern was not the old one of capital investment by the manufacturing industry stimulating all others but rather it was caused by increase in public investment, increase of private residential construction, and

* Chief Secretary, the Joint Research Society, The Iron and Steel Institute of Japan, Chiyoda-ku, Tokyo 100. 
increase in private consumption and expenditure.

By the type of business, industries of automobile, household electric appliance, construction, and machinery indicated recovery first. While these industries were regaining their vigor, changes began to appear in the demand for steels. Particularly noticeable was the increase in new products of large steel structures. Big projects of large scale public works have been launched: the construction of long bridges connecting Honshu and Shikoku scheduled to start in 1973 and the highway along the Tokyo Bay, of which a long under-sea tunnel is an important part, are only few examples.

In the field of exports of iron and steel, the Japanese steel industry announced extension of the self-imposed restrictions toward the United States on May 4. According to the announcement, the steel exports to the U.S. was to be limited to at an annual increase rate of $2.5 \%$ until 1974 . The government estimated that the steel exports would total $\$ 3004040000$ which is $4.4 \%$ decrease from the previous year. In reality the exports for the period of January to September, 1972, registered the level lower than that of the corresponding period in the previous year due to strikes of seamen labor union which lasted over three months starting in April and also because of effects of currency adjustment.

Since regulations over air pollution are made severer every year, the iron and steel industry has been making a large investment in pollution prevention and been endeavoring to secure fuels of low sulfur content. Thus, measures for preservation of favorable environments have become a topic of substantial concern for the industry.

\section{Technology and Facilities}

\section{Outline}

Production technology in the steel industry began to indicate several features as changes appeared in economic and social aspects. Qualitatively speaking, the steel production technology is emerging from the stage of merely meeting the rapidly increasing demand into an advanced stage of pursuance of higher objectives. In other words, though the technological developments in the iron and steel industry has been to improve productivity through mechanization, laborsaving, and adoption of continuous processes, as a consequence of the decrease in the demand for steel since the mid-1960, it began to turn its attention toward cultivation of new demands by developing new products of high quality and further toward establishment of production methods good for pollution control.

In the construction industry, one of the major consumers of steel, there has been a strong tendency for large scale and economic structures growing in the recent years. Development of large bloc construction method for construction of bridges, taming of the lift-up method in which components with a great weight are craned up quickly into position, etc. have made it possible to expand the scale of public construction works. Since much attention is being paid today on pump-up system of electric power plant, demand for high strength steel for pen stock is expected to increase. For realization of closed system ironmaking process, furthermore, the technology of nuclear powered ironmaking method is growing to be an important subject.

Investments in steel production facilities in 1972 remained inactive reflecting the supply-demand imbalance. Feeling the effects of depression, the iron and steel producers had to make several major changes in their projects: many construction works were postponed, halting periods extended, and completion delayed. As a result, the investment in general production facilities turned out to be lower than initially planned.

According to the results of investigation on capital investment plans carried out by the Industrial Fund Division of Industrial Structure Council in February, 1972, the iron and steel industry was planning to invest $¥ 675900000000$ (on construction basis) which is $12.7 \%$ ( $¥ 98000000000$ ) decrease from the previous year. The decrease ratio in the investment was greater than that in 1971.

As for investment by categories, in the ordinary steel category, the equipment investment decreased again as in the previous year since the recession in the iron and steel industry was expected to last for a considerable time. The investment in this field was recorded as $¥ 627500000000$ which is a $10.5 \%$ ( $¥ 7300000000$ ) decrease from the previous year. In the special steel category, because of the continuing low demand, the investment was only $¥ 21700000000$ or a $39.1 \%$ ( 13900000000 ) decrease from the previous year. In the ferro-alloy category, the investment is estimated to be $¥ 14800000000$ or a $44.4 \%$ (Y11 800000000 ) decrease in comparison with the actual record of the previous year. This is also due to postponement and cutting-back in construction projects of the industry.

Reflecting all these, major rolling facilities completed or commenced operation in 1972 numbered only five including those carried over from the previous year. The furnaces completed were four, namely, No. 1 of Oita Works and No. 4 of Tobata Works of Nippon Steel Corp., No. 2 of Kakogawa Works of Kobe Steel, Ltd., and No. 2 of Kashima Works of Sumitomo Metal Industries, Ltd. By the virtue of those and other furnaces that completed repair, productivity in ironmaking was expanded further as in the previous year.

In addition to these four new blast furnaces, No. 4 of Chiba Works of Kawasaki Steel Corp., which had been made idle for a long time to comform to the output reduction measures for the depression, was blown in before the scheduled operation-resumption. On the other hand, No. 2 of Sakai Works of Nippon Steel Corp. was removed from active list, while No. 6 of Higashida Works of Kobe Steel was disbanded. As a result the number of furnaces in Japan now stands at 66 (as of August).

In steelmaking, two converters were newly constructed making the total 90 (as of August.) The tendency of disposing with open hearth furnace continued 
in 1972 again, and the number of installation decreased to 31 in comparison with 46 in 1970.

Construction of continuous casting facilities is notably increasing. As a result of completion of new facilities, the number in the country reached 66 (as of June) and its annual productivity became $21270000 \mathrm{t}$, the world's greatest.

In the field of rolling, a cold mill was completed in January at Kakogawa Works of Kobe Steel, No. 2 large mill in February at Fukuyama Works of Nippon Kokan, and the world's first hydraulic screw-down type hot strip mill in March at Kimitsu Works of Nippon Steel. The No. 3 cold rolling mill and No. 2 rod mill were completed in July at Chiba Works and at Mizushima Works, respectively, of Kawasaki Steel.

Researches and efforts to develop new products were actively carried out by the industry, also. A noticeable feature in development of new products is that much efforts are placed in the products related to social development and prevention of environmental pollution. Further, high strength steels of good weldability and corrosion resistant steels were developed.

Automatic control of production is progressing. Utilization of computers became further popular. As of January, 1972, the iron and steel companies were using 409 computers for business and production purposes.

\section{Raw Materials}

Japan depends $95 \%$ of raw materials of iron and steel on imports from overseas. Because of this, efforts are made to reduce the transportation cost, hence the price of iron and steel, by using large ore carriers. Exclusive wharves to unload those carriers and raw materials yards directly connected with the wharves were constructed again in last year. In order to meet the ever increasing size of carriers, significant improvements were achieved in the field of construction technology of sea berth.

In May the raw materials wharf of Chiba Works of Kawasaki Steel was completed, and the operation started using a part of it as a raw materials yard. As the sea depth at the wharf ranges from 15 to 18 meters, ore carriers of $100000 \mathrm{t}$ can be moored. The same company further launched the construction of coal wharf at Mizushima Works. When completed, it will be a berth of 360 meters in length, 16 meters in sea depth, and will receive large carriers of $130000 \mathrm{t}$ class.

As for coal, efforts were to decrease the proportion of U.S. coal and to increase that from Australia and Canada. In addition, development in the preformed coke was noted: the preformed coke developed in 1972 needed no bituminous and was chiefly made of noncoking coal as its raw material. Experimental operations using this coke proved favorable and produced results similar to those obtained in using ordinary coke. Thus depending on the progress coke production technology may achieve, there will be a strong possibility to apply the preformed coke in large blast furnaces in the future.

In the field of coke oven, Nippon Kokan have bought licence of manufacturing the dry coke-quencher from U.S.S.R., Vsesojuznoje Exportno-Importnoje Objedinenije "Licensitorg." In the method, the coke is cooled by circulating nitrogen gas instead of water. The introduction of such kind of technology was the first in Japan.

In relation to sintering, pelletizing facility using slurry is under construction at Hirohata Works of Nippon Steel Corp. It works on the Alice-ChalmersShinko pelletizing method, and its production capacity, designed to be $3000000 \mathrm{t}$ per year at maximum, would be the world's largest when completed. With this facility working, the pellet ratio in this works would become $88 \%$ and, as it is designed to be able to take care of powder ores generated at other works, the overall sintering efficiency of the company will be improved greatly.

Another significant feature in the field of raw materials noticed in 1972 was that efforts were made to shift fuel to LPG (liquid petroleum gas) to lower the sulfur content for prevention of air pollution. Chiba Works of Kawasaki Steel, following the example of Mizushima Works of the same company, decided to install facilities, unloader, storage tank, pipe line system, and all. Conversion to LPG to a tune of $150000 \mathrm{t}$ per year is the immediate goal.

Nagoya Works of Nippon Steel also adopted the policy to utilize a large quantity of LPG. According to the company's project, a pipe line covering seven kilometers distance between this works and Nagoya Plant of Idemitsu Kosan Co., Ltd. will be laid to receive $100000 \mathrm{t}$ LPG annually starting from October, 1973. According to a plan, now under serious study, the shift to LPG will be $200000 \mathrm{t}$ in 1974 and $300000 \mathrm{t}$ in 1975 .

\section{Ironmaking}

As far as operation records are concerned, ironmaking technology did not show many significant changes in 1972. Increase of sintered pellet ratio and decrease of coke ratio seem to have reached the limit already. Light load operations to comply with the enforcement of the depression cartels resulted in lowering of tapping rate to below that of the previous year. In addition, there were several furnaces that became unstable.

Speaking of blast furnaces, construction of one with the world's largest inner furnace volume commenced in May. The furnace concerned is No. 5 of Fukuyama Works of Nippon Kokan, and its volume of 4400 to $4500 \mathrm{~m}^{3}$ is truly the largest in the world. In April, No. 1 of Oita Works of Nippon Steel (with furnace volume of $4158 \mathrm{~m}^{3}$, floor diameter of $14 \mathrm{~m}$, total height of $110 \mathrm{~m}$, was completed to run a ultra high top pressure operations at $2.5 \mathrm{~kg} / \mathrm{cm}^{2}$. The furnace employs stave cooling method, the technology introduced from U.S.S.R., and its production capacity is $10000 \mathrm{t}$ per day.

The No. 4 of Tobata Works of Nippon Steel was completed in an extraordinarily short time of one year and four months. In this furnace, a completely free standing structure system is employed for the 
first time in Japan. Stave cooler, movable armor, double doom external combustion type hot stove and other new facilities are featured.

The No. 2 of Kakogawa Works of Kobe Steel, to be completed in 1973, will have an inner furnace volume of $3843 \mathrm{~m}^{3}$ and uses U.S.S.R. type stave cooling method. A 7000 t per day output is expected from this furnace. A furnace top equipment introduced from Paul Wurth S.A. of Luxemburg is installed on the furnace.

Among auxiliary facilities of blast furnace completed in 1972, the important ones were: the $60000 \mathrm{~kW}$ blower of $10000 \mathrm{Nm}^{3} / \mathrm{min}$, completed in January for Oita Works of Nippon Steel, is the largest in the world; the boiler and blower now under construction at Mizushima Works of Kawasaki Steel is rated at $10000 \mathrm{Nm}^{3}$ $\min , 7 \mathrm{~kg} / \mathrm{cm}^{2}$ with a turbine of $70000 \mathrm{~kW}$ output. In the ferroalloy-making, the topic was the No. 5 electric furnace of Yahagi Iron Co., Ltd., the largest closed refining (ferro-silion) electric furnace in the world at $60000 \mathrm{kVA}$.

\section{Steelmaking}

In the 1972 record of converter operations, effects of production adjustment measures rather than of technological progress are recognized in unit consumption of oxygen and molten pig iron ratio.

As a new technique in the steelmaking field, Nippon Steel and Yamazato Electronites Co., Ltd. jointly developed an apparatus to measure amount of oxygen in molten steel applying the principle of oxygen differential battery. The appratus is being operated on an industrial scale at Hirohata Works. The circle concerned is hoping that the apparatus will be able to contribute to reduction of the amount of deoxidizing agent required and improvement of production efficiency.

Japan Special Steel Co., Ltd. developed a ladle refining method with electrodes heating apparatus. In this method, argon gas is blown in to stir the melt. It is expected to improve productivity.

Converters in operation as of August, 1972, were 90 including the two newly constructed. There was a tendency for the electric furnaces to become larger also.

\section{Continuous Casting Equipment}

Continuous casting facilities were installed at an increasing rate. Typically, No. 2 steel mill of Yawata Works of Nippon Steel achieved the world's new record of 106 consecutive hours of continuous casting of 89 charges with a continuous slab casting machine. This resulted in the output of $15354 \mathrm{t}$ slab. At the same time the development of tundish exchange method (sequence casting with sequence bloc) made the continuous continuous casting of different types and different sizes of molten steel real. According to a statistics compiled at the end of July, the number of continuous casting facilities installed in the country was 66 , and the annual production capacity was the world's largest, $21720000 \mathrm{t}$.

Some of major continuous casting facilities com- pleted in 1972 are described below. At Kashima Works of Sumitomo Metal Industries, a curved mold type Sumitomo Heavy Industries-Concast machine, designed to produce slabs for thick plates and hot rolling, was completed. All the processes from casting on down were automatically regulated for an annual production capacity of $1500000 \mathrm{t}$ maximum. Further, Nippon Kokan decided to import a rotary continuous casting equipment for the first time in Japan. As it will be used in conjunction with mandrel mills for seamless pipes, hollow cylinders are cast to eliminate all these processes of reshaping square billets into round billets then boring through the center. Since the rotary continuous casting method presents significant merits in lowering production cost by simplifying the production plant, it is drawing much attention as a clever rational investment in the field of special production control.

\section{Rolling}

As large scale construction projects, such as the bridge connecting Honshu with Shikoku, Kansai International Airport (floating island), and Tumeni (U.S.S.R.) oil field development, took clearer shape, it began to be appreciated that requirement for quality steel would soon be on a sharp increase. In response to this, the iron and steel industry began reinforcing or expanding their rolling facilities and pipe manufacturing facilities.

In the rolling, the demand for high strength steel plates is expected to grow further in the future, and to meet this each company is adjusting its production system. For example, at Yawata Works of Nippon Steel, a plate mill was added, and Mizushima Works of Kawasaki Steel is planning to construct a plate mill of the world's largest scale.

As for large-diameter pipe manufacturing facilities, a UOE machine was completed at Chiba Works of Kawasaki Steel, and another one is under construction at Kimitsu Works of Nippon Steel.

Major rolling facilities either completed or planned for construction in 1972 were as follows. In January, a cold strip mill of $80000 \mathrm{t}$ per month productivity was completed at Kakogawa Works of Kobe Steel on the technology introduced from U.S. Steel. The No. 2 large mill of Fukuyama Works, Nippon Kokan was completed in March for production of junior $\mathrm{H}$ shape steel, rails, and sheet piles. At the completion of this mill a full-scale production of rails started. It is equipped with a rail finishing mill which is capable of processing rails of up to $50 \mathrm{~m}$, the longest in the world.

A large mill completed in March at Kimitsu Works of Nippon Steel is for $\mathrm{H}$ steels with $80000 \mathrm{t}$ per month productivity. The finishing rolling stand of the mill is hydraulic screw-down.

Notably, this is the world's first wholly continuous $\mathrm{H}$ shape rolling mill and a large automatic sorting yard with automatic stacking storage was completed to serve the mill. The mill is also epoch-making in that the tension control is fully automated. In the rod steel mill completed at Mizushima Works of 
Kawasaki Steel in July the charging and discharging in and out of the reheating furnace as well as the bundling are automated: a big progress toward total labor saving has been made. The No. 2 thick plate mill planned at Kawasaki Steel will be the world's largest with the roll length of 210 inches and is expected to supply $200000 \mathrm{t}$ per month of ultra wide thick plates of $5000 \mathrm{~mm}$ in width to be used in the large diameter UOE pipe mill with maximum outer diameter of 64 inches now under construction at Chiba Works.

At Kimitsu Works of Nippon Steel a continuous annealing line for cold rolled sheet steels started operation. The line, now substantially made compact, is capable of taking any rolled sheets including those for deep drawing. Not only a great saving in labor and time but a noteworthy improvement in quality and uniformity will be attained.

A continuous annealing furnace was completed at Fukuyama Works of Nippon Kokan, also.

\section{Steel Processing and Surface Treatment}

As the scale of construction works has expanded to meet needs in the big projects of social development and preservation of favorable public environments, the demand for shorter construction period has become acute. This is reflecting on the demand for steel becoming directed more towards large structurals and particularly high strength steels. As an answer, world's first rolled box section steel has been developed. This product will find its usefulness as frame steel or as temporary stay of trass bridges. Further, demand for pipe stakes grew rapidly as construction works on soft grounds, bridges, wharves, breakwaters, and so on, became intensives. Sumitomo Metal Industries developed automatic welding method of pipe stakes which were actually used for foundation pipes at South Harbor Bridge in Osaka. Nippon Kokan and Kobe Steel also developed automatic welding methods of pipe stakes.

As for construction materials, light weight uninflammable parting strips have been developed. Deck plates came into a wider use, and steel beams processing system operated on numerical control using N.C. shearing machine as well as automatic pipe ends cleaner were devloped.

Demand for surface treated plates as construction materials seems to grow further in the future. The iron and steel makers are endeavoring to expand surface treating facilities.

In spite of the low-level demand for steel materials in general, demand for bond plates remained comparatively stable and so Nippon Steel completed an electric zinc galvanizing line for bond steels at Kimitsu Works. Kobe Steel also decided for construction of an electric zinc galvanizing equipment with monthly productivity of $8000 \mathrm{t}$ at Kakogawa Works. At Chiba Works of Kawasaki Steel operations of the second galvanizing line with monthly production of $17000 \mathrm{t}$ started. The firm is planning to remodel the No. 1 galvanizing line into a tin-free plate (chromium plated plates) and plate galvanizing line.

\section{Facilities for Environmental Pollution Control}

It is expected that the investment in facilities related to prevention of environmental pollution amounted to approximately $¥ 90000000000$ in 1972. This is a $134 \%$ increase over the previous year. The ratio of such kind of investment to total investment was $13.6 \%$ while in 1971 it was $8.7 \%$. Significant activities in the field of environmental pollution control are explained below. Stacks are made taller today in order to decrease density of sulfur dioxide gas. For example, in sintering field which is characterized by a large quantity of exhaust air, a chimney of $200 \mathrm{~m}$ in length is under construction.

At Nagoya Works of Nippon Steel a large Tacax desulfurization plant of 150000 to $200000 \mathrm{Nm}^{3}$ per hour capacity for gas from coke oven is being constructed today. A desulfurization and decyanization plant for coke oven gas was installed at Kashima Works of Sumitomo Metal Industries. An open experiment of a model desulfurization plant was carried out at Keihin Works of Nippon Kokan in March. The model plant of $150000 \mathrm{Nm}^{3} / \mathrm{hr}$ capacity as constructed with a governmental subsidy and was installed at a sintering plant.

Dust collectors were installed at many plants, and a total shop dust collecting equipment for an electric furnace plant, for example, was constructed at Topy Industries. The apparatus commenced dust-collecting operations for the three $30 \mathrm{t}$ electric furnaces in June and achieved a favorable result. The equipment is the largest total shop dust collecting equipment in Japan with a suction capacity of $94 \mathrm{Nm}^{3}$ per minute.

A converter slag treatment plant was completed at Oita Works of Nippon Steel. This plant has a roof, and treatment works are performed by a bulldozer and a shovel car operated by a completely remote control system.

In addition to equipment of disposing waste water, various kinds of facilities to treat waste materials were installed in 1972. One of the most significant was that completed at Hirohata Works of Nippon Steel. It is an epoch-making equipment designed to treat waste water from all the lines of cold rolling plant.

\section{Others}

Major products developed in 1972 are explained in the following. Kawasaki Steel introduced a new stainless steel, namely, River Light 430 LT (containing titanium). This stainless steel has merits of both the ferrite and austenite alloys and is suitable for applications in apparatuses for prevention of environmental pollution and house roofs. As a construction material, Nippon Kokan developed COLOR SP using market grade silicon paint and pigments. This one is reported to possess better weatherbility, corrosion resistance, and workability than existing acryl plastics.

Taiyo Steel Co., Ltd. developed a new type of color plates with a superior sound proof property.

As a product related to prevention of air pollution, Kobe Steel developed compound plates for sound insulation. This product consists of two sheets between 
Table 1. Foreign techniques introduced in 1972 (Class A)

\begin{tabular}{|c|c|c|c|c|c|}
\hline $\begin{array}{l}\text { Date ap- } \\
\text { proved by } \\
\text { BOJ }\end{array}$ & Accepted by & Rendered by & Nationality & Item & Term \\
\hline 1972. 1.20 & Nissei Sangyo & $\begin{array}{l}\text { Ruthner Industrie- } \\
\text { planungs, AG }\end{array}$ & Austria & $\begin{array}{l}\text { Manufacture of neutral salts elec- } \\
\text { trolytic pickling line for stainless } \\
\text { plates }\end{array}$ & $\begin{array}{l}\text { From date of valida- } \\
\text { tion to } 1972.4 .30 *\end{array}$ \\
\hline 1972. 1. 21 & $\begin{array}{l}\text { Nippon Steel (Sub- } \\
\text { licensee) Kobe Steel }\end{array}$ & $\begin{array}{l}\text { Vsesojusnoje } \quad \text { Ex- } \\
\text { portno-Importnoje } \\
\text { Objedinenije "Li- } \\
\text { censintorg" }\end{array}$ & U.S.S.R. & $\begin{array}{l}\text { Stave cooling and water cooling of } \\
\text { blast furnace }\end{array}$ & $\begin{array}{l}\text { From date of valida- } \\
\text { tion to } 1977.6 .26\end{array}$ \\
\hline 1972. 1. 21 & Nippon Steel & $\begin{array}{l}\text { Philadelphia Gear } \\
\text { Corp. }\end{array}$ & U.S.A. & $\begin{array}{l}\text { Philadelphia Gear Type Converter } \\
\text { reclining facilities }\end{array}$ & $\begin{array}{l}10 \text { years from date } \\
\text { of validation }\end{array}$ \\
\hline 1972. 2. 7 & $\begin{array}{l}\text { Sumitomo Shoji } \\
\text { Kaisha }\end{array}$ & $\begin{array}{l}\text { Heinrich Koppers, } \\
\text { G.m.b.H. }\end{array}$ & W. Germany & $\begin{array}{l}\text { Designing, manufacturing, installa- } \\
\text { tion, and operation of high tem- } \\
\text { perature hot blast stove for blast } \\
\text { furnace }\end{array}$ & $\begin{array}{l}\text { Unlimited time from } \\
\text { date of validation }\end{array}$ \\
\hline $1972,3.17$ & $\begin{array}{l}\text { Hitachi Shipbuild- } \\
\text { ing \& Engineering }\end{array}$ & $\begin{array}{l}\text { Rurgi Chemi und } \\
\text { Hütten }\end{array}$ & W. Germany & $\begin{array}{l}\text { Sintering facilities and cooling fa- } \\
\text { cilities for iron ore and non-ferrous } \\
\text { metal ores }\end{array}$ & $1972.4 .24-1982.9 .30$ \\
\hline 1972. 3.23 & $\begin{array}{l}\text { Kurimoto Iron } \\
\text { Works }\end{array}$ & $\begin{array}{l}\text { Hermann Raport \& } \\
\text { Co. G.m.b.H. }\end{array}$ & W. Germany & $\begin{array}{l}\text { Manufacture of auxiliary facilities } \\
\text { for blast furnace and hot blast stove }\end{array}$ & To 1977.1 .31 \\
\hline 1972. 3.23 & Otani Jukogyo & Mannessmann & W. Germany & $\begin{array}{l}\text { Continuous casting of billet by } \\
\text { Mannessmann method }\end{array}$ & To 1981.12 .31 \\
\hline 1972. 4.17 & Maeda Seisakusho & $\begin{array}{l}\text { Kingsland Drum \& } \\
\text { Barallel }\end{array}$ & U.S.A. & Reproduction of used steel drums & $\begin{array}{l}\text { From date of valida- } \\
\text { tion to } 1983.12 .31\end{array}$ \\
\hline 1972. 6.1 & Nihon Kogyo Senjo & Havy Burton Co. & U.S.A. & $\begin{array}{l}\text { Elimination of copper in ferrous } \\
\text { oxide precipitates from steels }\end{array}$ & $\begin{array}{l}\text { From date of valida- } \\
\text { tion to expiration of } \\
\text { license }\end{array}$ \\
\hline 1972. 6.1 & Tanaka Seisakusho & Union Carbide Corp. & U.S.A. & $\begin{array}{l}\text { Method of repairing scarfing fa- } \\
\text { cilities and manufacturing of spare } \\
\text { parts }\end{array}$ & $\begin{array}{l}10 \text { years from date } \\
\text { of validation }\end{array}$ \\
\hline 1972. 6.8 & $\begin{array}{l}\text { Mitsui Shipbuilding } \\
\text { \& Engineering }\end{array}$ & Gränges Essen AB & Sweden & $\begin{array}{l}\text { Unsintered pellet manufacturing } \\
\text { facilities }\end{array}$ & To 1977.3 .31 \\
\hline 1972. 6.1 & $\begin{array}{l}\text { Mitsubishi Heavy } \\
\text { Industries }\end{array}$ & $\begin{array}{l}\text { Arthur G. Muchie } \\
\text { \& Co. }\end{array}$ & U.S.A. & Manufacture of sintering machine & $\begin{array}{l}5 \text { years from date } \\
\text { of validation }\end{array}$ \\
\hline 1972. 5.18 & Nippon Kokan & $\begin{array}{l}\text { Vsesojusnoje Ex- } \\
\text { portno-Importnoje } \\
\text { Objedinenije "Li- } \\
\text { censintorg " }\end{array}$ & U.S.S.R. & Manufacture of dry coke quencher & $\begin{array}{l}10 \text { years from date } \\
\text { of validation }\end{array}$ \\
\hline 1972. 5.11 & $\begin{array}{l}\text { Nippon Stud Weld- } \\
\text { ing }\end{array}$ & $\begin{array}{l}\text { TRW. Inc., United } \\
\text { Car Division }\end{array}$ & U.S.A. & Patent license on no-hole fastener & $\begin{array}{l}\text { From date of valida- } \\
\text { tion to expiration of } \\
\text { patent }\end{array}$ \\
\hline 1972. 6.29 & $\begin{array}{l}\text { Nippon Benkan } \\
\text { Kogyo }\end{array}$ & $\begin{array}{l}\text { Alpha Tube Mill, } \\
\text { Ltd. }\end{array}$ & Switzerland & $\begin{array}{l}\text { Method of applying plastic coating } \\
\text { on plumbering pipes, pipe joints, } \\
\text { and assemblable piping parts for } \\
\text { houses }\end{array}$ & $\begin{array}{l}15 \text { years from date } \\
\text { of validation }\end{array}$ \\
\hline 1972. 7.19 & Nippon Yakin Kogyo & $\begin{array}{l}\text { Creusot-Loire } \\
\text { (Group Marine } \\
\text { Schneider) }\end{array}$ & France & $\begin{array}{l}\text { Manufacture of low temperature } \\
\text { special nickel- and ferro-alloys }\end{array}$ & $\begin{array}{l}10 \text { years from date } \\
\text { of validation }\end{array}$ \\
\hline 1972. 8.14 & Taihei Kogyo & National Slab Ltd. & Canada & $\begin{array}{l}\text { Manufacture of spherical expansive } \\
\text { slag }\end{array}$ & $\begin{array}{l}5 \text { years from date } \\
\text { of validation }\end{array}$ \\
\hline 1972. 8.5 & Kawatetsu Kenzai & H.H. Robertson Co. & U.S.A. & $\begin{array}{l}\text { Manufacture of steel composite floor } \\
\text { material }\end{array}$ & $\begin{array}{l}10 \text { years from date } \\
\text { of validation }\end{array}$ \\
\hline 1972. 9.12 & Amati & Collating A.G. & Switzerland & $\begin{array}{l}\text { Manufacture of nails for automatic } \\
\text { nailing machine }\end{array}$ & $\begin{array}{l}9 \text { years from date of } \\
\text { product completion }\end{array}$ \\
\hline 1972. 9.7 & Asahi Pipe Lining & $\begin{array}{l}\text { Centrifugal Lining } \\
\text { Ltd. }\end{array}$ & U.K. & $\begin{array}{l}\text { Mortar lining of inner surface of } \\
\text { pipes }\end{array}$ & $\begin{array}{l}10 \text { years from date } \\
\text { of validation }\end{array}$ \\
\hline 1972. 9.27 & Chiba Seikan & $\begin{array}{l}\text { Aluminium Com- } \\
\text { pany of America }\end{array}$ & U.S.A. & $\begin{array}{l}\text { Manufacture of simple can opening } \\
\text { apparatus }\end{array}$ & $\begin{array}{l}10 \text { years from date } \\
\text { of validation }\end{array}$ \\
\hline 1972. 9. 28 & Nippon Kokan & $\begin{array}{l}\text { Hoeschwerke Aktien- } \\
\text { gesellschaft }\end{array}$ & W. Germany & $\begin{array}{l}\text { Exchange of technical information } \\
\text { and know-how concerning welded } \\
\text { pipes for pipe line }\end{array}$ & $\begin{array}{l}\text { From date of valida- } \\
\text { tion to } 1975.12 .31\end{array}$ \\
\hline 1972.9. 96 & Nippon Kinzoku & $\begin{array}{l}\text { The International } \\
\text { Nickel Co., Inc. }\end{array}$ & U.S.A. & $\begin{array}{l}\text { Method of Coloring and surface } \\
\text { treatment of chromium bearing } \\
\text { metals }\end{array}$ & $\begin{array}{l}7 \text { years from date } \\
\text { of validation }\end{array}$ \\
\hline 1972. 9.30 & $\begin{array}{l}\text { Nippon National } \\
\text { Seikan } \\
\text { Nippon Light Metal }\end{array}$ & $\begin{array}{l}\text { National Can Over- } \\
\text { seas Corp. }\end{array}$ & U.S.A. & Manufacture of aluminum can & $\begin{array}{l}10 \text { years from effec- } \\
\text { tive date of agree- } \\
\text { ment }\end{array}$ \\
\hline 1972. 10. 9 & Nippon Arcos & $\begin{array}{l}\text { Electric Autogen } \\
\text { procede Arsco S.A. }\end{array}$ & Belgium & $\begin{array}{l}\text { Manufacture of flux containing } \\
\text { wires for automatic and semi-auto- } \\
\text { matic welding }\end{array}$ & $\begin{array}{l}2 \text { years from date } \\
\text { of validation }\end{array}$ \\
\hline 1972.10.9 & Japan Steel Works & $\mathrm{X}$ Alloy Inc. & U.S.A. & $\begin{array}{l}\text { Manufacture of } \mathrm{X} \text {-alloy bimetallic } \\
\text { sylinder }\end{array}$ & $\begin{array}{l}2 \text { years from date } \\
\text { of validation }\end{array}$ \\
\hline
\end{tabular}

* Industrial proprietary rights, etc. 
Table 2. Japanese investments abroad in 1972

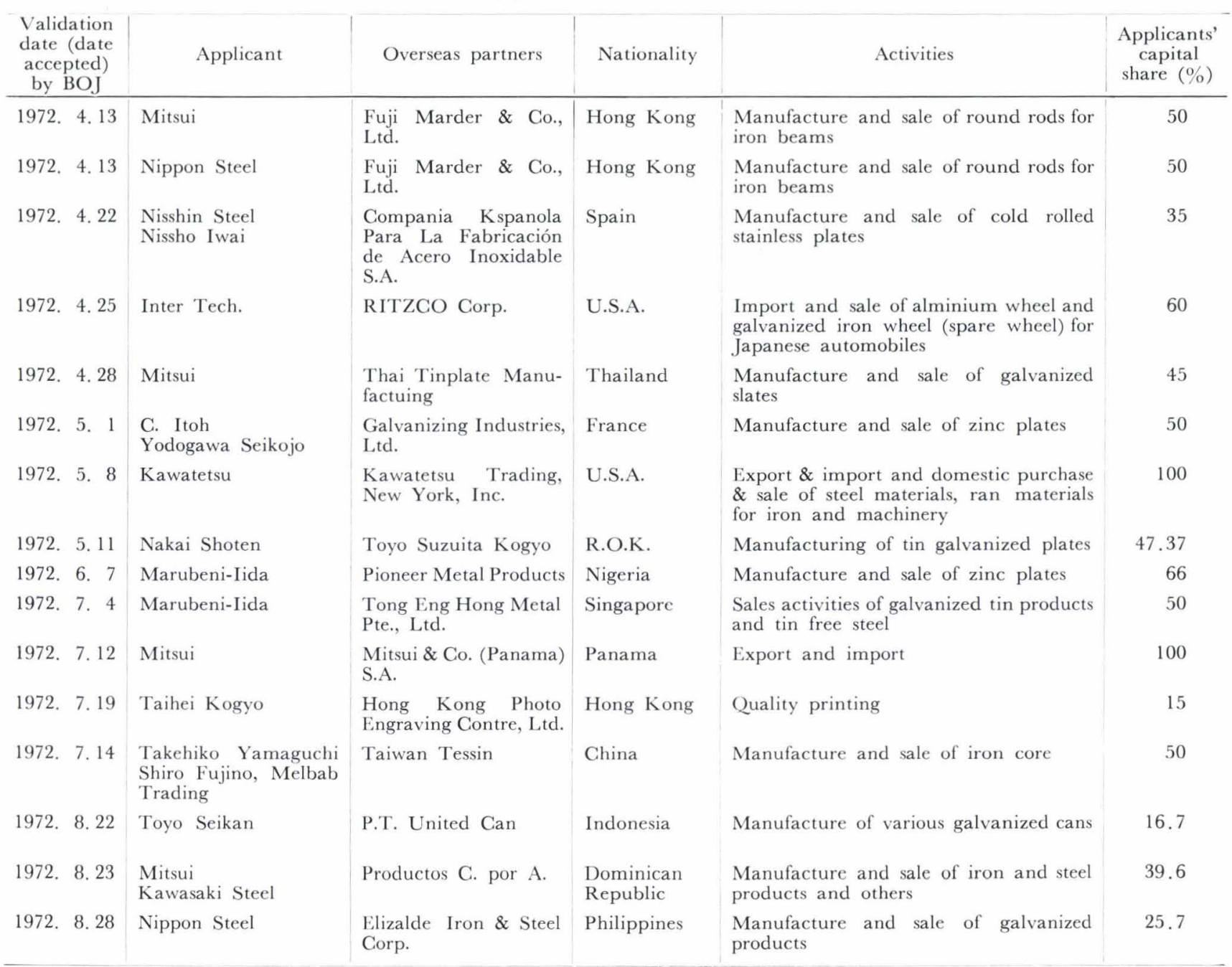

which plastics with high damping coefficient is inserted.

Of the production control computers; the computer system completed at Fukuyama Works of Nippon Kokan in June comprises terminal computers installed at every intermediate processing line so that not only the state of progress at each stage but of the overall status of plate processing can be centrally controlled.

At Mizushima Works of Kawasaki Steel and at Kakogawa Works of Kobe Steel computer systems comprehensively controlling slabbing and plate processes were constructed.

As for new testing / research facilities, the rod pipe testing center completed at Kimitsu Works of Nippon Steel is noted. The testing capacity of the center is designed to meet the production rate of $140000 \mathrm{t}$ crude steel per year and known to have the highest standard of accuracy and efficiency.

\section{Technological Exchange with Foreign Coun- tries and Overseas Investment}

Of the technologies introduced from abroad (Class A), those that are deeply connected with the iron and steel industry is listed in Table 1.

Nippon Steel imported the stave cooling method of blast furnace from U.S.S.R., while Nippon Kokan bought the manufacturing right of coke dry quencher from the same source.

In the Class B, Japan Metals and Chemicals Co., Ltd. was licenced by the Union Carbide Corp. (U.S.A.) for silicon alloys containing strontium, an additive for cast iron. Wean Japan, Inc. obtained designing and manufacturing rights of continuous electric tin galvanizing facilities from Wean United, Inc. (U.S.A.)

Investments to abroad applied for validation during 1972 are shown in Table 2. Overseas development projects were in many cases related to iron and steel industries of developing countries. The Japanese investments, except for those in integrated steel mills at Pohang (R.O.K.) and Usiminas (Brasil), were limited to ones smaller than rolling plant in scale, and many of them were directed to manufacturing and sale of zinc plates.

The Japanese iron and steel industry has been cultivating international cooperation, for example, by rendering technical assistance to various countries. In October an investigation team organized by the government was dispatched to Indonesia at the request of the Indonesian government for the purpose of preparing a master plan of the iron and steel industry for the latter.

Also in order to investigate feasibility of expansion 
plan of Pohang Iron Works in Korea, an investigation team will be sent from the Japanese government. In November Chinese metallurgical engineering delegation came for inspection of the Japanese iron and steel industry.

\section{Activities of Various Research Societies in ISIJ}

\section{Joint Research Society}

In the Joint Research Society, research activities concerning iron and steel manufacturing technology are actively conducted by 15 committees and 21 subcommittees, Electric Furnace Subcommittee and Rolling Theory Subcommittee having been promoted to committeeship as of October 1. Major activities of the committees are described in the following.

\section{Ironmaking Committee}

The Ironmaking Committee holds two meetings each year, and in 1972 it selected " Effects of Operation Factors on Gas Distribution in Blast Furnace" and "Measures and Problems in Lowering Fuel Ratio" as common research themes. With respect to the former theme, examinations were made on gas distribution in the furnace in connection with permeability, gas utilization ratio, and fuel ratio. As for the latter theme, comprehensive examinations were made on factors for lowering fuel ratio from both operational and facilities points of view. In addition to the common themes, special lectures and papers on other themes were presented at the committee meetings.

Coke Subcommittee held two meetings to discuss common themes of "Mechanization and Automation in Coke Oven, Experiences and Problems," "Size Control of Coke for Blast Furnace," "Control of Humidity in Coke," and "Size Control of Coking Coal."

\section{Steelmaking Committee}

Activities of the Steelmaking Committee were conducted by the committee itself and Ingot Mold Subcommittee. As the Electric Furnace Subcommittee became an independent committee in October, there remains only one subcommitte under this committee.

The committee held the usual three meetings in two years in which various discussions were presented on researches under common themes of "Researches on Improvements on Manufacturing Facilities (including Continuous Casting and Degassing)," "Studies related to Air Pollution," "Studies on Economic Use of Power," and "Introduction of New Facilities." From the 53rd meeting, another theme on "Safety and Prevention of Accidents " was added to the above, and serious discussions were conducted.

The committee is compiling responses of each member on inquiries on the policy and contents of common research themes in order to decide future committee activities to make them meaningful to the members.

The Ingot Mold Subcommittee has been conducting three research meetings every two years. At the 24th meeting, members exchanged valuable opinions on such a complex subject as that concerning the board design for casting mold.

\section{Electric Furnace Committee}

The Electric Furnace Committee was organized in October, 1972. It has two subcommittees. The First Subcommittee is composed of companies mainly producing mild steels with electric are furnace of $30 \mathrm{t}$ or more and the Second Subcommittee consists of companies mainly producing alloy steels with electric arc furnace of $30 \mathrm{t}$ or more.

Each subcommittee holds two meetings annually. The First Subcommittee has 12 members companies today and is expected to have more. Each subcommittee is expected to carry out energetic activities in the future.

\section{Special Steel Committee}

Special Steel Committee is a large committee with over 100 participants at each of 2 annual meetings. In order to prevent themes to overlap with those of the Electric Furnace Committee, the Special Steel Committee places a greater emphasis on quality of special steels. Particularly in recent years, many research papers have been presented on special melting operations such as ESR and VAR. This committee is sponsoring International Symposium on ESR to be held in June, 1973, in addition to other useful activities.

\section{Rolling Theory Committee}

The Rolling Theory Subcommittee changed its title to the Rolling Theory Committee in October, 1972. In the three meetings held in February, June, and November, steel companies, university laboratories, and rolling mill makers participated to discuss following points: (A) Examination of Cold Deformation Resistance, (B) Characters of Rolling Lubrication, (C) Characteristics of Automatic Control Such as Roll Bending and AGC, (D) Theoretical Analysis Concerning Hollow Rolling, and (E) Examinations of Roll Forming.

Currently the committee is planning a joint experiment on rolling lubrication properties. It is expected that effects of high speed rolling, friction coefficient, surface properties, etc. will be clarified through the experiment.

\section{Steel Plates and Sheets Committee}

The Steel Plates and Sheets Committee consists of Blooming and Slabbing, Plates, Hot Strip, and Cold Strip Subcommittees. The Blooming and Slabbing Subcommittee examined "Yield Improvement and Cost Reduction Measures," "Descaling Methods," and "Quality Control and its Problems" as common themes and further examined "Utilization of Subcontractor Companies in Finishing Works."

The Plates Subcommittee discussed "Rolls for Plate Mills" and presented a lecture on "Problems in Rolls for Plate Mills and Prospects for Future" (Japan Steel Works, Ltd.) It further examined "Present Conditions and Problems of Shot and Painting Operations" and "Labor Productivity." " Special Report of Plates Subcommittee" is being prepared for publication in the second quarter of 1973.

The Hot Strip Subcommittee examined common themes of "Computer Operations" and "Measures to Reduce Roll Unit Cost." "Improvements in 
Flatness" and "Fact-finding Research for Improvement of Roll Surface Defects " were also presented at the meeting as independent research papers.

The Cold Strip Subcommittee studied "Counterrusting Facilities and Rust Prevention Measures for Cold Rolled Products" and "Rolling Rolls." Other research papers presented in the meeting covered capacity, quality improvement, and economization at processes from pickling line to the finishing line.

Besides the above-mentioned activities, the committee completed editorial preparations for 2 volumes of manual, "Hot Rolled Sheets" and "Cold Rolled Sheets." These publications are in printer's shop at the times of this writing; they will be published either in January or February of 1973.

\section{Sections and Wire Rods Committee}

This committee consists of three subcommittees of Large Sections, Medium and Small Sections, and Wire Rods. Since classification between the large sections and the medium and small sections was not very clear, and participants to the latter had become too many to secure a sufficient discussion time, a survey on classification and management of the committee meetings was made among members. On the basis of the replies to the survey, the counsellors and chief editors decided to adopt the classification by size in accordance with Wire Rods Manual. Consequently 3 firms will be transferred to the Large Sections from the Medium and Small Sections.

The Medium and Small Sections Subcommittee used to conduct discussions at 2 meeting halls on the same themes in the past. However, the subcommittee decided to improve management of activities by dividing the meetings on 'mild steel and alloyed steel ' and by adopting different themes of discussion for each meeting hall.

The Large Sections Subcommittee investigated and studied "Present Conditions and Problems of Shipping Operations " and "Present Conditions and Problems of Rolling Roll." It tried for the first time a paper presentation meeting of the users on " Problems of Large Shapes and Sections from the Viewpoint of the Users." The subcommittee also published "Special Report of Large Sections Subcommittee" in November, for which editorial preparations were carried on from the previous year.

The Medium and Small Sections Subcommittee investigated and discussed maintenance of facilities, simplifying and rationalization of rolling and adjustment, assignment of works related to production, prevention measures and management system for product scars, etc.

The Wire Rods Subcommittee examined coil bundling method, improvement of net working time, entrance and exit guides, and boundary operations.

\section{Steel Pipes and Tubes Committee}

The Steel Pipes and Tubes Committee studied control of environments (particularly measures to prevent noise and disposal of waste acid), problems concerning shipping (packing, bundling, and marking), labor-saving in finishing and testing, and management of subcontractors. In the future in-site trans- portation facilities and problems in production of special shape pipes will be examined.

The Seamless Pipes Subcommittee discussed mechanisms of abnormal thickness increase at pipe ends at drawing mills and automatic control of mill operations, both pertaining to Mannessmann mills. In the future it will continue to study high speed piercing method and items concerning mandrell mill. In connection with hot extrusion, factors for variations in crop length, method of scrap disposal, determination of size of extruding tools, and other topics were discussed. The joint experiment on "Extrusion Deformation Resistance" will be carried on. Glass lubrication, extrusion speed, pipe size changes, and extrusion tools are also subjects of further examination.

The Welded Pipes Subcommittee considered problems of personnel requirement for electric seamed pipes and application of NDI facilities. In connection with submerged arc welded pipes, surface treating facilities, problems of coil joining, secondary processing, inspection by outlooks and size measurement, etc. were selected as themes of discussion. The subcommittee will concentrate on studies of NDI equipment and cost reduction measures in the next term.

\section{Iron and Steel Analysis Committee}

Activities of the Iron and Steel Analysis Committee were carried out by the committee itself as well as by its subcommittee, Chemical Analysis Subcommittee, Photoelectric Emission Spectroscopic Analysis Subcommittee, Fluorescent X-ray Analysis Subcommittee, and Nonmetallic Inclusion Analysis Subcommittee. The committee customarily holds 2 annual meetings.

The Chemical Analysis Subcommittee held the usual 3 to 4 meetings every year, and proposals for JIS on atomic absorption spectroscopic method were drafted. Also analysis methods of sulfur, vanadium, cobalt, niobium, nitrogen, and other elements were examined.

The Photoelectric Emission Spectroscopic Analysis Subcommittee held the two annual committee meetings in addition to the two annual meetings, and the basic policies of the subcommittee were decided on. The activities included amendment to JIS 1253 and a joint experiment to seek detection limit for each element.

The Fluorescent X-ray Analysis Subcommittee held 4 to 5 committee meetings in addition to 2 annual subcommittee meetings. Major activities of 1972 included preparation of standard testing materials, a joint experiment on correction coefficient, $d_{j}$, etc. In the coming term the subcommittee will conduct analysis of powder samples.

The Nonmetallic Inclusions Analysis Subcommittee held 4 annual meetings and conducted a joint experiment on extraction of precipitates in $\mathrm{Fe}-\mathrm{Mo}-\mathrm{C}$, $\mathrm{Fe}-\mathrm{W}-\mathrm{C}$, and $\mathrm{Fe}-\mathrm{Nb}-\mathrm{C}$ alloys. Electrolysis method and acid method were applied for each alloy in the tests and results are forthcoming.

\section{Heat Economy Technique Committee}

The Heat Economy Technique Committee has been studying instrumentation for various furnaces, improvement in operation, and examination of energy 
control. Recently the committee has studied various problems concerning heat economy. Refractory Material Subcommittee increased the number of committee members and enlarged the scope of its researches. Thus the field of research by the division expanded to cover the whole processes of a steel plant.

\section{Instrumentation Committee}

In addition to the activities as the committee itself, there were other activities taken by Weighing and Measuring Subcommittee and several other committees. The committee held 3 meetings in which measuring method, development of sensor terminal, utilization of computer, new products for instrumentation, etc. were covered from ironmaking to final product as themes of researches. In addition, research papers were presented energetically by steel producers and measuring instrument makers. The 50th Anniversary meeting was held in spring, 1972, in Tokyo.

The subcommittees of the Instrumentation Committee convened 5 to 6 study meetings during one and a half year. Thermometer Scale Standardization Subcommittee and X-ray Thickness Gage Subcommittee compiled results of study as reports. These reports covered present status of the field and requests for other industries, then were presented at the committee meeting.

Also two subcommittees, one on education concerning maintenance and safety and the other for radiation pyrometry were newly established; their studies are expected to be completed in a year and half.

The Weighing and Measuring Subcommittee selected as the common agenda the examination of responses to a survey conducted on electronic weighers, and held one meeting. Problems in large weighers were also examined in the meeting. The findings will be compiled as a report to be presented at the next subcommittee meeting (spring, 1973) by Electronic Weighers Subcommittee.

\section{Facilities Research Committee}

In connection with "Examination of Harbor Facilities for Raw Materials of Iron and Steel in 1970 's," the counsellors of the committee investigated and discussed " Measures for Environmental Protection at and around Raw Material Wharves" and prepared a report thereon. Further, the division selected a new theme of "Examination of Loading and Unloading of Products" and is collecting basic source materials.

The report on the above will be presented at the June-July discussion meeting in 1973.

\section{Quality Control Committee}

The committee held two meetings as planned. " Practical Examples of Various Measures for Prevention of Repetition of Claims " and "Present Status and Problems of Production and Quality Control by Computers" were common research themes of 1972. Themes of independent studies included voluntary inspection, subcontractor management, efficiency improvement for plant experimentations, worker's complaints system, etc., which were actively discussed.

Further in connection with testing facilities and testing method, requests of establishment of an organi- zation for exchange of views among engineers in charge of machine testings to guarantee quality of steel products have mounted. The committee is making a study on this.

\section{Plant Engineering Research Gommittee}

The Plant Engineering Research Committe is comprised of Iron- and Steelmaking Plant Engineering Research and Rolling Mill Plant Engineering Research Subcommittee. The committee is a joint research organization of iron and steel producers and machineries fabricators. The Iron- and Steelmaking Plant Engineering Research Subcommittee considered " Dust Collector for Casting Shop," "Problems and Solutions for High Temperature Hot Stove," "Designs, Problems, and Countermeasures in Safety Maintenance for Dust Collector for Sintering," "Pellet Sintering Facilities," and "Problems and System of Ironmaking Facilities " in its survey. The results of the investigation were edited into a reference book with comments. The committee held a lecture meeting on "Future of Blast Furnace" and "Effective Utilization of Blast Furnace Gas" also. The iron and steel producers submitted a report on "Dust Collecting Method for Converter Plant" while machinery makers placed their emphasis on equipment in their reports on "Various Continuous Casting Facilities." In the discussion period of these papers active exchange of questions and answers were noticed.

The Rolling Mill Plant Engineering Research Subcommittee made studies on wire rod facilities and slabbing facilities. With respect to the wire rod facilities, inquiries were made on coupling and spindle, roll bearing, coiler, shear, stand, and roll-exchange facilities, etc. to each participating member company. On the basis of answers obtained, the subcommittee compiled a reference book with discussion notes. Further, the subcommittee presented a lecture on "Wire Cooling Line." With respect to slabbing facilities, there emerged a plan to distribute questionnaires on vertical roll drive system, horizontal roll drive system, manipulator and roller table, shear, and maintenance system at slabbing mills among the member companies in January, 1973. The answers to these will be integrated in a lecture meeting on "Vibration Analysis of Rolling Mill Drive System " and "Slab Cooling Facilities."

\section{Committee on Utilization of Nuclear Energy}

The Committee on Utilization of Nuclear Energy consisting of System Subcommittee, five subcommittees, and three experimentation subcommittees has been engaged in research activities for utilization of multipurpose high temperature gas cooled reactor in ironmaking processes.

The System Subcommittee in 1971 examined economic factors involved in an ironmaking plant using nuclear energy at the scale of $10000000 \mathrm{t} /$ year crude steel output. Further, it compiled results of studies previously carried out by each subcommittee and is making a comprehensive examination of the ironmaking pattern utilizing nuclear energy in the production process.

The First Subcommittee examined economy for an 
imaginary model plant of $10000000 \mathrm{t} /$ year crude steel output whose entire conversion processes are all run by the electricity generated at an exclusive nuclear power plant.

In the Second Subcommittee investigations and researches by a working group are continuing on fluidized bed furnace which is considered to be as favorable as shaft furnace for direct reduction using nuclear energy. In connection with shaft furnace, a small scale experiment was conducted by Shaft Furnace Subcommittee. In 1972 the subcommittee completed an experiment of reduction by mixed gas $\left(\mathrm{H}_{2}+\right.$ $\mathrm{CO})$, thus bringing the series of experimental projects carried on since 1970 to conclusion.

In the Third Subcommittee, a working group has been evaluating the feasibility of high temperature nuclear reactors in ironmaking on practical and quantitative basis.

The Fourth Subcommittee examined such issues as heat exchange method in high temperature heat exchanger, structure and designing, materials and sizes in detail. It prepared experimental plans for investigations of steam cracking of methane, characteristics of heat exchange between helium and steam, hydrogen permeability of heat resisting metals, dehydrogenization of helium gas, and behavior of heat resisting metals in high temperature helium gas and reduction gas, to be conducted in a high temperature helium loop. This experimental plan is a continuation of that undertaken by Heat Exchanger Subcommittee sice 1971.

The Fifth Subcommittee has examined various processes for obtaining inexpensive reducing gas, particularly in connection with raw materials. The use of asphalt was proposed by the subcommittee, and was duly tested experimentally for various kinds of asphalt by the Reduction Gas Subcommittee, valuable data were obtained.

As one of measures for environmental conservation, the Ministry of International Trade and Industry selected a research and development of ironmaking method using nuclear energy as one of the National Projects for 1973 with a view of developing a new ironmaking method in the closed system. The Committee on Utilization of Nuclear Energy has been instrumental in preparing the research plan. As these large scale projects start, it may become necessary to reexamine policies and systems of activities of the committee.

\section{Joint Society on Iron and Steel Basic Research}

Five committees were active in the Joint Group for Basic Research of Iron and Steel that is jointly sponsored by the ISIJ, the Japan Institute of Metals, and the Japan Society for Promotion of Science. The followings are reviews of major activities of each group.

\section{Solidification Committee}

The Solidification Committee was established in 1971 and entered into its second year; it began practical researches in 1972. Members are divided into three groups of (1) Solidification and Heat Conduction of Steel, (2) Mechanism of Formation of Solidification Structures, and (3) Solidification of Steel and
Mechanism of Segregation. Up to the present three meetings have been held to report and discuss the results of research.

\section{Strength and Toughness Committee}

In its fourth year, the Strength and Toughness Committee reported on structural strength and toughness of steels through 4 annual meetings. As a part of its activities, it organized a symposium concerning "Behaviors and Appraisal of Retained Austenite" in cooperation with the 3rd division of the Japan Society of Metals. The committee is planning to hold a symposium in every February through 1974. Since the committee is scheduled to terminate its activities in the business year of 1973, results of research activities will be compiled and reported in near future.

\section{Delayed Fracture Committee}

In the 3rd year of its history, the committee's activities were noticeably intensified. Behaviors of hydrogen were studied phenomenologically on realization that they are essential to clarify mechanisms of delayed fracture, and various theories were advanced on the basis of these experiments. On November 22, 1972, the committee convened the 1st symposium to present intermediate reports.

\section{Recrystallization Committee}

The purpose of the Recrystallization Committee is to clarify problems of recrystallization of iron and steel. This field contains far more complex and numerous unknown factors than in the case of nonferrous metals. Practical activities of the committee were concentrated on a few specific themes in the field. In 1972 the major research theme was " Effects of Copper Addition on Recrystallization and Texture Structures of Iron." In order to compile results of activities of the committee since its establishment in 1970 , the committee is preparing a report for publication.

\section{Solid Massspectrometric Analysis Committee}

Starting in 1972 the Solid Massspectrometric Analysis Committee began its activities as a division of the Joint Group. The committee aims at improving accuracy of quantitative measurement in the analysis of trace elements in metals and plans to clarify factor by factor problems of ion micro-analyzer using common samples. Experiments were carried out on solid elements and gas component of metals as well as for improvements of instruments. The committee is planning to analyze concentration distribution in the direction of depth in surface layer of metal with the ion micro-analyzer.

\section{Other Research Committees}

Other organizations of ISIJ engaged in joint researches include Committees of Creep, Standardization, Experimental Blast Furnace, Continuous Steelmaking, Education, Desulfurization Test of Exhaust Gas, and Heat Resistant Alloys for Jet Engine.

\section{Creep Committee}

\section{(i) Creep Testing Subcommittee}

This subcommittee has been participating in a common international testing on creep rupture carried by 8 members composed of Japan and European nations. 
In the past $100 \mathrm{hr}, 1000 \mathrm{hr}, 3000 \mathrm{hr}$, and $10000 \mathrm{hr}$ tests were completed. At present the subcommittee is carrying out the $30000 \mathrm{hr}$ test. From May 3 to 5, 1972, an international conference was convened in Dusseldorf in connection with the common international testing. The subcommittee sent two members to the meeting as the Japanese delegation.

(ii) High Temperature Tensile Test Subcommittee

From its establishment in 1967 to 1971 the High Temperature Tensile Test Subcommittee made 5 comprehensive tests on heat resistant materials produced in Japan. In 1972 it compiled the test results as a report.

The 5th joint testing was carried out in two kinds: series A (tests of significant difference according to JIS between automatic control and manual control) and series B (examination of various control methods for loading through Rüders band deformation and serrated stress-strain curve deformation). The results of those tests necessitated reexamination of JIS (G0567-1966) as follows: (1) amendments in specifications for strain rate, (2) possible specification by $1 \%$ proof stress for austenitic steels, and (3) determination of work standards for manual testing. They will be carried over to 1973 .

The subcommittee was entrusted with the reviewing of JIS for high temperature tensile tests by Industrial Science and Technology Agency, and duly prepared a questionnaire to draw opinions from participating members in the Creep Committee on which to base formal recommendations. For this work as well as for the reviewing of the JIS pertaining to creep test, the subcommittee established 9 groups.

(iii) Sample Subcommittee (Creep Rupture Specimen Bank)

The Sample Subcommittee has been compiling statistical data by distributing standard samples from a specimen bank to the members participating in the test on the basis of responses on questionnaire distributed in the previous year.

(iv) Data Sheet Subcommittee

This subcommittee has been compiling a series of data related to standardization of creep testing method and preparing a draft of standards (JIS G0567-1966) concerning high temperature tensile test method of iron and steel. It also continued compilation of data on high temperature tensile test. In 1972 the subcommittee published "Japanese Creep Rupture and Elevated Temperature Tensile Deta-Part 1, Low Alloy Steels" as a special report. For 1973 it is planning to collect data on creep, creep rupture, and high temperature tensile test for stainless steels for the second volume of the report.

(v) National Research Institute for Metals Creep Data Sheet Subcommittee

Since 1966 the NRIM Creep Data Sheet Subcommittee has been engaged in selection of steel types for creep tests in close cooperation with the Institute. It makes recommendations to the Institute of steels and test conditions for which preparation of data sheet are desired. In 1972, 4 steels in Class A and 4 in Class B were selected according to the number of requests made in the survey of 1971 .

Further in connection with preparation of high temperature strength data sheet on welding joints, it decided to recommend that the data sheet representing creep rupture properties of welded joints be made for more important steels whose creep rupture strengths are already known. Thus it submitted to NRIM a recommendation that those types in Class $\mathrm{A}$ are the ones for which data sheets are most desired while those in Class B rank second in such requirement in connection with creep rupture properties on welding joints.

\section{(vi) JIS Draft Subcommittee}

The JIS Draft Subcommittee was established in 1971. It prepared a draft for JIS on creep rupture testing method and conducted investigation and research on high temperature relaxation method. In 1972 the Industrial Science \& Technology Agency decided to entrust preparation of a draft for JIS on relaxation to the subcommittee. In order to handle the works anticipated, it was decided to establish another subcommittee directly under the Standardization Committee consisting of members from the JIS Draft Subcommittee and others from circles concerned. The JIS Draft Subcommittee made a comparative examination of standards of relaxation tests of various countries and reported on the present status of relaxation tests in Japan. Further for the purpose of understanding existing status and finding requests for preparation of a draft for JIS, the subcommittee drew up a questionnaire and distributed it among all members of the Creep Committee and those concerned with P.C. Responses to the questionnaire were compiled and submitted to the newly established Relaxation Subcommittee of the Standardization Committee.

\section{Standardization Committee}

The Standardization Committee has been conducting reexamination of JIS on iron and steel, preparation of drafts for new JIS standards or amendments to JIS, examination and preparation of comments on international standards to ISO, dispatch of delegates to international meetings of ISO, compilation and preparation of data sheets, etc. in 2 committees and 21 subcommittees.

(i) ISO Iron and Steel Committee

As a regular member of ISO, the committee sent totalof 36 delegates with qualified $\mathrm{P}$ status to ISO TC 17 conferences in the following fields so as to reflect Japanese opinions on standards: SC 1 (Analysis), SC 3 (Structural Steels, 2 meetings in 1972), SC 4 (Heattreated Steels), SC 9 (Tin Plates), SC 10 (Pressure Vessel steels), SC 10/Tube-SG, SC 10/ETP-SG, and SC 12 (Hot and Cold Rolled Steel Sheets, Galvanized Steel Sheets).

In addition, it dispatched total of 5 delegates to ISO/TC 67 (Materials and facilities for natural and petroleum gas industry), TC/67/SC 1 (Line pipe), and SC 5 (Casing, tubing, drill pipe).

Activities of the ISO Iron and Steel Committee are expanding every year. Documents examined by the committee last year numbered 296 (as of November 15), 
consisting of 239 (including 79 on analysis and test methods, and 160 on steels) for TC 17 , and 57 for TC: 67.

\section{(ii) Data Sheet Committee}

For the purpose of preparing a data sheet on mechanical properties in consideration of mass effects of 6 steels of SMn3, SMnC21, SCr4, SCr22, SCM4, and SCM21, the committee made common experiments on $25 \phi, 50 \phi, 100 \phi$ test pieces of each type following similar tests on SC's (S35C, S45C, and S55C) and CrMo steels (SCM3, SCM22). From these experiments, the committee compiled data on yield point, tensile strength, elongation, reduction of area, $2 \mathrm{~mm} \mathrm{U}$ and $2 \mathrm{~mm} \mathrm{~V}$ Charpy impact values, hardness in cross section, hardness after tempering, grain size, and so on. The committee is preparing to publish "Data Sheet Series" from data compiled in 1971 on SC steels CrMo steels, and high temperature tensile tests.

(iii) Seven Standing Subcommittees

Seven standing subcommittees such as Mild Steels Subcommittee and Special Steel Subcommittee are reviewing 24 standards of JIS, preparing drafts of amendments to $8 \mathrm{JIS}$ standards for structural alloyed steels and conducting preliminary experiments for the purpose of manufacturing standard test pieces for calibration of Charpy impact testing machine. The Draft Preparation Subcommittee with participation of producers, users, and neutral third parties prepared drafts for new JIS on hot dipped aluminum coated steel sheets and amendments to JIS for spring steels. Further Sheet Standards System Investigation Subcommittee examined standardization system of sheets manufactured by strip mill and surface treated sheets with emphasis on mild steels including quality steels.

\section{Experimental Blast Furnace Committee}

The purpose of the Experimental Blast Furnace Committee is to cooperate in research investigation and development of ironmaking technology through the utilization of the experimental blast furnace installed at the Institute of Industrial Science, the University of Tokyo and thus to contribute to technological development in ironmaking. In 1972 the Institute performed the 23rd test operation for 15 days starting on July 25.

On of recent trends in blast furnace operations is that hydrogen content of the furnace gas is increased due to a large amount of the blown in supplementary materials (heavy oil, etc.) Accordingly, there has risen a need for a sufficient clarification of the role of hydrogen gas in the reaction process of ores. The test operation of 1972 was carried out to investigate behaviors of hydrogen gas in the furnace by blowing natural gas from tuyere under the theme of "Research Concerning Behaviors of Hydrogen Gas in Blast Furnace" and clarified how hydrogen contributes to reduction.

\section{Continuous Steelmaking Research Committee}

The Continuous Steelmaking Research Committee conducted following activities in 1972 .

The 59th steelmaking experiment: on the spot observation, January 20, 1972

The 12th steelmaking subcommittee meeting:
March 2, 1972

The 60th steelmaking experiment: on the spot observation, March 30, 1972

The 13th steelmaking subcommittee meeting: May 25, 1972

The 2nd 60th steelmaking experiment: on the spot observation, July 14, 1972

The 61st steelmaking experiment: on the spot observation, November 10, 1972

The 62nd steelmaking experiment: on the spot observation, December 7, 1972

Those experiments were carried out at NRIM. In addition to the direct observations, the Management Subcommittee has been taking responsibility of planning future research activities.

\section{Education Committee}

With the aim of advancing science and technology on iron and steel ISIJ established Education Committee in February, 1971, in order to plan and promote educational activities. The committee convened the counsellors' meeting which planned a symposium and published a report which was distributed among the concerned circles receiving much valuable responses.

\section{Desulfurization Test of Exhaust Gas Committee}

The committee was established in December, 1970, by participation of 10 blast furnace makers (members of The Japan Iron and Steel Federation and ISIJ) for the purpose of conducting experiments concerning industrialization of desulfurization facilities for sintering plants in iron works as a part of environmental conservation program. The total cost of the experiment is estimated to be $¥ 160000000$. Before starting the tests, the committee selected " Experiment for Industrialization of Recirculation Process of Desulfurizing Sintering Plant Waste Gas as Plaster by Ammonium in Coke Oven Gas" as its main research theme. It received 1971 subsidy from the Research and Development of Important Technology Fund amounting to $¥ 150000000$ from MITI and carried out practical experiments at Keihin Works of Nippon Kokan. The experiment concerning the ammonium sulfate method was completed in October, 1972, and the results published. In 1972 with another subsidy of $¥ 58000000$ it conducted "Experiments for Industrialization of the Recirculation Process to Recover Sulfur Dioxide Gas in the Sintering Plant Waste Gas as Gypsum by Ammonium." The committee is planning to complete the gypsum method by July, 1973, and the report will be prepared on it, too.

\section{Research Committee for Heat Resistant Alloys for Jet Engine}

Since its establishment in 1969, the Research Committee for Heat Resistant Alloys for Jet Engine has developed a new thermal fatigue testing method. It has been endeavoring to clarify thermal fatigue properties of representative alloys used as jet engine materials today by this new test method. With the MITI subsidy of $¥ 15000000$ from the Research and Development of Important Technology Fund in 1972, the committee came to own 3 testing machines for thermal fatigue tests, and together with the two pre- 
viously installed, the committee has been conducting tests on various materials described below in order to improve properties of heat resistant alloys and to establish effective production method for them: (1) comparison of forged to cast materials, and effects of various factors such as grain size and amount of gas components on thermal fatigue properties, (2) investigation of thermal fatigue properties of $64 \mathrm{BC}$, a newly developed material, and (3) comparison of materials produced abroad and those manufactured in Japan under the same specification.

\section{International Iron and Steel Technical Committee}

This committee was established in 1969 as the Japanese counterpart of the Technical Committee of International Iron and Steel Institute. In 1972 it performed 4th investigation on operation practices of sintering, blast furnace, and converters. With respect to the converters, Working Group for Converters took major responsibility in compilation of data from 16 countries which are participating in IISI Technical Committee. Further from 1972, the range of activities of the committee expanded to handle international conferences concerning iron and steel technology in general. In this capacity, the committee called for or recommended papers on behalf of the 3rd Iron and Steel Symposium organized by the United Nations Industrial Development Organization, the Symposium on Casting organized by Southeast Asia Iron and Steel Institute, and the International Iron and Steel Congress 1974.

\section{Fourth International Conference on Vacuum Metal-} lurgy

The Fourth International Conference on Vacuum Metallurgy will be held in Keidanren Kaikan, Tokyo, from June 4 to 8, 1973, under the co-sponsorship of ISIJ, the Japan Society of Metals, and the Vacuum Society of Japan. Preparations of the conference are being made. Some 400 participants and 80 papers are expected. The 3rd circular will be sent out in February, 1973. Since the iron and steel industry is much concerned with advancement into new fields and realizes importance of developing new technology, this conference on vacuum metallurgy would undoubtedly present valuable contributions. There will be participants from U.S.S.R. and Eastern Europe countries reflecting the age of international exchange.

10. Fourth International Symposium on Electroslag Remelting Processes

ISIJ is sponsoring the Fourth International Symposium on Electroslag Remelting Process to be held for two days of June 7 and 8, 1973, at Keidanren Kaikan, Tokyo. Approximately 160 participants will attend the symposium and 30 papers will be presented. Preparations are being made to make the symposium memorable for promotion of electro-slag technology and to cultivate international exchange.

11. The Fourth Japan-USSR Joint Symposium on Physical Chemistry of Metallurgical Processes

The Fourth Japan-USSR Joint Symposium on Physical Chemistry of Metallurgical Processes is scheduled to be held for 3 days, May 31 to June 2, 1973. This meeting is organized by ISIJ and will be held in Keidanren Kaikan, Tokyo, also. An academic mission of approximately 10 delegates will be sent from U.S.S.R. Twenty to twenty-five papers will be presented at the symposium. It is believed that the meeting will further cultivate academic exchange between U.S.S.R and Japan as in the past symposia

\section{Outlook for 1973}

For this country, both at home and internationally, the year of 1972 was the year of many changes in political and economic fields. The public opinion of the land strongly favored advancement of a welfare type economy. In international relations restoration of diplomatic relations with China was realized much earlier than expected when Tanaka Cabinet was formed. Despite the adjustments on international currency at the end of 1971 , the growth rate of the Japanese exports did not slow down and the foreign currency reserve climbed up to $\$ 18000000000$ which easily invited scornful criticisms from abroad.

At the beginning of 1972 the iron and steel industry had a general fear that the long depression would not cease that year. However, active investment in public facilities by the government and successful formation of depression cartels by the industry itself began to return favorable results, and the industry started its way to recovery.

In spite of such signs of recovery, the iron and steel industry should remind itself that there still exists a substantial imbalance between demand and supply and should make best efforts to sustain mutual and cooperative spirit at the domestic and international levels thus far cultivated at the time of depression.

This does not mean that the industry can be content with results of temporary measures however successful they may seem to be, since the speed of technological innovation is unbelievably fast today. From such a viewpoint and in consideration of limited energy resources in the country much effort is called for in development of ironmaking technology using atomic energy as one of important production methods for the coming age. Thus further efforts are required for intensifying the technology development activities. On the other hand continued efforts are required in the field of basic researches which are the foundation of new production technology as well as in the field of improving existing technology.

With regard to practical problems related to the industry such as enlarged size of vessels, bridges, and beams, for example, more researches would be necessary to improve and develop fabrication technology such as welding.

Today it is recognized both in Japan and abroad that the Japanese iron and steel industry is in the leading position because of the advanced level of its facilities and technology. The number of requests from abroad on the Japanese industry for plant exports, operational training, establishment of joint venture companies, transfer of know-how, etc. is increasing. This proves the high standard of the Japanese technology.

The agreement has been reached between Japan 
and China to resume diplomatic relations. It is expected that such development in international relations would encourage foreign countries, particularly Southeast Asian countries, to demand the Japanese industry to step up technological assistance and cooperative activities in the future. Sincere responses on the part of the Japanese industry to such requests will undoubtedly be effective in relaxing the severe attitudes and hostility directed against economic growth and achievement of Japan.

Another factor which could contribute to improvement of technological standard and promotion of international cooperation is exchange of opinions and friendship through international meetings on science and technology. In this respect, we should interest ourselves more to convening such international meetings in Japan or participating in similar meetings held abroad as frequently as possible.

The last but not the least factor which requires our special notice is the conservation of favorable environments by the industry. The public has been emphasizing the terror of public hazards, and the industry itself is not free from ill effects of environmental pollution. Until recently when developing a new production technology the first priority was placed on furtherance of productivity. The general direction in developmental efforts was for larger size, automation, and labor-saving. From now on the industry should invest amply in environment conservatory facilities, the issue which have been neglected in comparison with other objectives. Preventive measures fundamental or practical, for air pollution, water contamination, and noise should be sought out. Such positive attitudes by the industry is absolutely necessary if the industry desires to grow as the basic industry for the people and society. Whether the environmental pollution problem can be successfully solved or not will naturally influence the course of welfare of the people engaged in the iron and steel industry, also. Only when the iron and steel industry succeeds in bettering the living environments, would it secure a prolonged prosperity with popular support.

In concluding this article, I would like to express my deep appreciation for valuable cooperation and assistance rendered in preparation of this review by $\mathrm{Mr}$. Akira Uehara and by the staffs of Investigation Department of the Japan Federation of Iron and Steel and Technical Department of the Iron and Steel Institute of Japan. 